Chơi cổ phiếu không thể như... đánh lô, đề

Việt Anh

Báo Người Lao Động

April 15, 2007

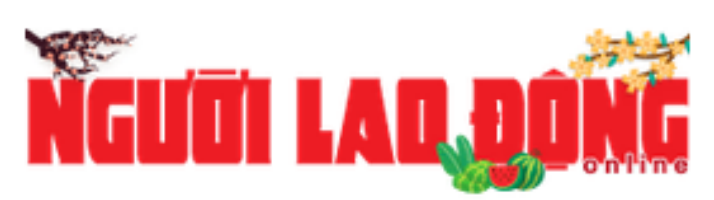

https://nld.com.vn/kinh-te/choi-co-phieu-khong-the-nhu-danh-lo--de-186268.htm 


\section{Chợi cổ phiếu không thể như... đánh lô, đề}

15-04-2007 - 12:36 PM | Kinh tế

\section{f Chia sẻ It Thích 0}

Thị trường chứng khoán VN thời gian qua lên xuống thất thường làm nản lòng không ít nhà đầu tư không chuyên. Theo các chuyên gia, hiện tượng này có mặt tích cực khi giúp các nhà đầu tư bớt dần cảm tính, trả lại đúng bản chất của thị trường chứng khoán. Phóng viên Báo Người Lao Động đã có cuộc trao đổi với TS Vương Quân Hoàng nghiên cứu viên cấp cao ĐH Tổng hợp Bruxelles (Bỉ) đồng thời là người sáng lập trang web hữu ích về những kiến thức kinh doanh và đầu tư www.saga.vn

. Phóng viên: Tiến sĩ nhìn nhận như thế nào về sự điều chỉnh của thị trường chứng khoán (TTCK) VN hiện nay? Có nên mở rộng đầu tư chứng khoán vào thời điểm chứng khoán sụt giá hiện nay? - TS Vương Quân Hoàng: Thị trường bây giờ không giống như thời kỳ 2002-2004, số lượng tiền sẵn sàng cho đầu tư đã tăng lên rất nhiều. Lựa chọn hàng hóa cũng nhiều hơn. Ngoài ra, luồng tiền chảy ra chảy vào thị trường giờ đây cũng không còn gây ra xáo trộn đáng kể nên không xảy ra các cuộc khủng hoảng. Như vậy không có lý do gì để từ bỏ thị trường này. Theo tôi, cái cần từ bỏ là cách thức suy nghĩ đơn giản hóa quá đáng và việc cẩu thả trong hành vi đầu tư như hiện nay. Từ nay tới lúc hàng hóa được đưa ra ở quy mô đầy đủ theo dự kiến của Chính phủ VN, và nếu không có đột biến thì thị trường sẽ không thể tăng đồng loạt theo hiệu ứng kiểu bầy đàn trước đây. Sẽ có một số nhóm cổ phiếu đã niêm yết giá vẫn tăng trưởng được nhưng sẽ dao động có lên có xuống chứ không thể có xu hướng một chiều nữa. Trong khi đó sẽ rất nhiều cổ phiếu trong số khoảng 200 loại cổ phiếu hiện tại đang niêm yết sẽ phải có điều 
chỉnh giảm vì đây là mức giá trên trời. Với giá đó, giới đầu tư nghiêm túc không chấp nhận được. . Đã là nhà đầu tư chứng khoán thì không thể không quan tâm những bản phân tích tài chính của các công ty đang niêm yết cổ phiếu. Vậy sao các nhà đầu tư ở VN lại chẳng thèm ngó ngàng tới tham số rất quan trọng này mỗi khi quyết định đầu tư vào cổ phiếu nào đó?

MEIKO - Tin tài trơ

Giúp cải thiện chỉ số đường huyết hiệu quả với chi phí hợp lý chỉ từ 25 ngàn/ngày(+159k reached)

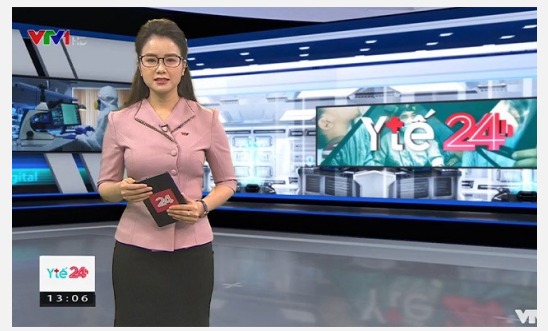

- Trên thực tế các nhà đầu tư VN ít nhận được các phân tích có giá trị, vì phần lớn cái gọi là phân tích của các công ty chứng khoán, trừ một số ít tạm xem là nghiêm túc mà tôi quan sát được, đều có tính chất là "công cụ bán hàng" cho các công ty chứ không phải là đưa thông tin để bảo vệ quyền lợi thị trường và nhà đầu tư. Không nhất thiết phải tin tất cả những gì các công ty chứng khoán nói mà còn cần quan sát cả hành vi của họ nữa, các xung đột lợi ích tiềm tàng và các vấn đề khác như thông tin, trục lợi... Vấn đề là không phải ai cũng hiểu rõ bản chất và người ta chưa đánh giá đúng mức rủi ro đó khi rất đông người đang rất sốt ruột mua cổ phiếu. . Thưa ông, các nhà đầu tư nên ứng xử ra sao trong thời điểm hiện nay? - Cần phải bình tĩnh, tỉnh táo quan sát thị trường, nghiên cứu thật kỹ chính nhu cầu đầu tư và nhu cầu tài chính của bản thân nhà đầu tư. Hình thành những mục tiêu "khả thi" để có thể theo đuổi. Nếu không là nhà đầu tư chuyên nghiệp thì nên đầu tư vào chứng chỉ quỹ đầu tư, chứ không nên phung phí tiền bạc và say sưa với những cơn mộng vô thường. Xã hội sẽ càng ngày càng phân cấp rõ, chứ không thể là phong trào toàn dân chơi chứng khoán, chơi theo cảm hứng giống như đánh lô, đề. Nói thật bất cứ kinh tế gia nào nhìn cảnh đầu tư vừa rồi trên TTCK VN cũng đều... hãi hùng, đặc biệt là thị trường tự do, thường bị hiểu sai là OTC. Đối với người có khả năng sẵn sàng 
chấp nhận rủi ro và chấp nhận có thể đầu tư lâu dài thì đây là khoảng thời gian để quan sát và lựa chọn những cổ phiếu "ưa thích". . Thời gian qua, khi mà TTCK lên xuống thất thường thì trong giới kinh doanh "đồn" hiện đang tồn tại một thế lực tài chính đủ mạnh có thể thao túng TTCK VN? Ông có ý kiến gì về vấn đề này? - Nếu tồn tại một thế lực như vậy thì đây là một tin rất xấu. Tôi thấy chưa có căn cứ gì để kết luận, nhưng khi nào nhiều người tin vào việc đó thì tác động của nó khiến chúng ta tin rằng việc tồn tại thế lực đó là có thật. Để hình dung đáp án cho câu hỏi này, ta cần xem hai khía cạnh. Thứ nhất, TTCK có thể thao túng được hay không? Câu trả lời là: Được. Đó là vì quy mô thị trường tuy tăng lên, nhưng vẫn chưa phải lớn. Hơn nữa, giao dịch tập trung vào một số cổ phiếu quan trọng, chỉ một số thông tin về khả năng tăng lượng cung cổ phiếu, lập tức giá đã có xu hướng giảm. Khía cạnh thứ hai là người ta có động cơ để thao túng TTCK VN không? Theo tôi là có! Nhưng động cơ này trong giai đoạn hiện nay là chưa rõ rệt. Một số công ty có xu hướng tạo ảnh hưởng cho cổ phiếu của mình thì đúng, nhưng cả thị trường thì phải là một số tập đoàn có thể tập hợp các nguồn tiền. Tôi nghĩ chưa phải lúc này. Nhưng nghi vấn thì cũng tốt, vì nó là vệt "khói" giúp Ủy ban Chứng khoán Nhà nước và Trung tâm Giao dịch Chứng khoán lưu tâm, kịp thời đưa ra biện pháp phòng ngừa. . Theo ông, TTCK VN sẽ tiếp tục "lạnh" hay "nóng" lên trong thời gian tới? - Có thể nói giai đoạn sắp tới là giai đoạn tương đối ổn định, là giai đoạn ổn định thứ hai của TTCK VN nhưng khác với thời kỳ 2002-2004. Đây là giai đoạn ổn định sau khi tăng trưởng tương đối mạnh và số lượng chứng khoán sắp tăng mạnh. Nếu giữ giai đoạn này ổn định, thì chính sách vĩ mô của Chính phủ sẽ có nhiều cơ hội thành công. Thời gian tới, TTCK VN sẽ ít có khả năng suy thoái kéo dài, nhưng tăng trưởng mạnh là một xác suất không cao.

. Xin cảm ơn ông.

Việt Anh thụ̣c hiện

\section{f Chia sẻ It Thích 0 Quan tâm}




\section{Tài liệu tham khảo:}

[1] Hoàng, V. Q. (2004). Hiệu ứng GARCH trên dãy lợi suất thị trường chứng khoán Việt Nam 2000-2003. Tạp chí Ứng dụng Toán học, 4(2), 15-30.

[2] Hoàng, V. Q. (2007). Văn minh làm giàu \& Nguồn gốc của cải. Nxb Chính trị quốc gia, Hà Nội.

[3] Hữu, N. V., \& Hoàng, V. Q. (2007). Các phương pháp toán học trong tài chính. Nxb Đại học Quốc gia, Hà Nội. 